\title{
13. Has macroeconomic stability since 1992 been due to Keynesianism, monetarism or what?
}

On Wednesday 16 September 1992 (known at the time as 'Black Wednesday'), heavy selling of the pound on the foreign exchanges forced it out of the European exchange rate mechanism (ERM). The UK's exit from the ERM was regarded at the time as both a failure of economic policy and a national humiliation. As it is now 15 years later, the event can begin to be analysed from a wider historical perspective. The central point is surprising, but clear. The decade following the pound's expulsion from the ERM was a triumph for British economic policy-making. The sterling crisis of September 1992 did not foreshadow increased instability, but instead was followed by greater macroeconomic stability than in any previous phase of the UK's post-war history (and probably than ever before in British history). Black Wednesday became Golden Wednesday.

The paradoxical outcome was highlighted by Sir Alan Budd, Chief Economic Adviser to the Treasury between 1991 and 1997, in the Julian Hodge Institute lecture in April 2002. The lecture, entitled 'The quest for stability', noted that new policy-making arrangements introduced in late 1992 had 'exceeded all expectations'. ${ }^{1}$ Not only had the UK had 'remarkably stable growth' in the 1990s, but it had 'survived the recent world recession better than any other major economy'. Budd's lecture was a valuable starting point for discussion, but it prompted two further questions. The first related to quantification. If the decade after September 1992 was better than earlier decades, how much better was it? Without an answer to this question, the impression of greater stability after 1992 remained only an impression. The second and perhaps more fundamental question was one of explanation. On the whole, the UK's record in macroeconomic management between 1945 and 1992 had been mediocre. Indeed, this mediocrity had come to be seen not only as an aspect of a larger economic inadequacy as the UK's share in world output and exports declined year by year, but as inevitable and never-ending. What happened in 1992 which ended (or at any rate interrupted) the unsatisfactory record? (This essay relates to the numbers in the decade from 1992. A brief appendix reviews 
the period since the third quarter [Q3] of 2002. The improvement in stability certainly now lasts until mid-2006.)

Budd argued in his lecture that economic policy-making in the years from September 1992 had a considerable degree of continuity, with a focus on inflation targets and a depoliticization of decision-taking. One way of assessing the stability of the decade after September 1992 is to compare it with previous periods in which economic policy and outcomes also had some sort of unity. In this essay a comparison is made with two earlier periods - a stop-go period from the third quarter Q3 1945 to Q2 1971, and a boom-bust period from Q3 1971 to Q3 1992. In the 26-year period from the end of the Second World War to Q2 1971, the UK participated in the Bretton Woods system of fixed exchange rates. Although the pound suffered a heavy devaluation in 1949, it was then kept within the narrow limits (\$2.78-\$2.82) set by the Bretton Woods rules until November 1967. This fixity of the exchange rate conditioned all economic policy-making. The world economy was far more stable than it had been in the inter-war period, but the need to defend the pound's exchange rate led to frequent policy changes in the UK and economic activity fluctuated in mild stop-go cycles.

The system of fixed exchange rates came to end with the suspension of the dollar's convertibility into gold in August 1971. Apart from a brief flirtation with the European 'snake' in the spring of 1972, the UK had a floating exchange rate against other major currencies until October 1990, when it joined the ERM. With no explicit external constraint on policy, monetary policy was extremely loose in the 18 months from autumn 1971, and a wild boom developed. Although a degree of order was restored to policy-making by the introduction of money supply targets in 1976, the operation of these targets was widely deemed to be unsatisfactory. With much uncertainty about the best policy regime for the UK, the conduct of policy was often erratic. Big swings in interest rates and inflation were accompanied by two big boom-bust cycles (from 1971 to 1974 and from 1986 to 1992), and one smaller cycle (from 1977 to 1982). The period can be fairly described as 'the boom-bust period'. The analytical task becomes the comparison of macroeconomic stability in three periods - the stop-go period, the boom-bust period, and the decade of stability from September 1992.

The next step is to propose the macroeconomic magnitudes whose variability is to be measured. Macroeconomic instability has at least three dimensions - instability in demand and output, instability in inflation, and instability in interest rates. Of course, other policy goals are relevant. For 
example, a case could be made that fluctuations in employment have a more meaningful impact on people's welfare than fluctuations in demand and output. Much of the post-war period was indeed characterized by official concern to maintain so-called 'full employment'. However, the labour market saw such extensive structural and legislative changes over the decades that unemployment statistics have a quite different significance in 2002 from what they had in 1945. By contrast, the concept of gross domestic output has remained much the same, despite great changes in its composition and level. Instability in the growth of gross domestic product is therefore chosen as the first indicator. (The growth rate is the annual rate and a quarterly series is analysed.)

Financial instability is measured here by instability in inflation and interest rates, but again there is an alternative. For many companies - particularly manufacturing companies exporting a high proportion of their output instability in the exchange rate is equally or more important. Despite this, the exchange rate plays no role in the current exercise. One problem is that businesses value stability in the real exchange rate (that is, the exchange rate adjusted for differences in inflation between nations) as well as stability in the nominal exchange rate, but unfortunately there are several ways to measure the real exchange rate. Arguably the omission of the exchange rate handicaps the stop-go period in a comparison with the boom-bust period and the final decade, a point that needs to be remembered in the comparison of the three periods.

A further complication is that the phrase 'the instability of inflation and interest rates' begs the questions 'which inflation rate?' and 'which interest rate?' As the policy target in the final post-ERM decade was expressed in terms of RPIX (that is, the retail price index excluding mortgage interest rates), it might seem logical to use RPIX in the stop-go and boom-bust periods. But there is a difficulty, in that mortgage interest rates were included in the retail price index only from 1976, and the index is not wholly comparable before and after this date. A sensible answer is to regard both the 'headline' RPI and the 'underlying' RPIX as valid inflation measures. Hence the instability of both needs to be measured, and that is what is done here.

The post-war period saw a number of far-reaching changes in the structure of the British financial system. Associated with these changes were shifts in official emphasis on different interest-rate concepts, as well as a few redesignations of interest-rate concepts whose underlying economic meaning was quite stable. Fortunately, one instrument - the three-month Treasury bill - has changed little over the decades. Treasury bill rate has therefore been chosen as the measure of interest rates for current purposes.

So the increase in GDP, the annual rates of RPI and RPIX change, and the Treasury bill rate are taken to be representative of output changes, 
inflation, and interest rates respectively. Broadly comparable statistical series are available for all three variables over the entire 1945-2002 period under consideration. ${ }^{2}$ Their instability is measured here by the standard deviation. (An alternative measure - the coefficient of variation [the standard deviation divided by the mean] - does not add much. It could even be positively misleading with inflation, as successful policy leads to a lower mean inflation rate. For any given value of the standard deviation, that would raise the coefficient of variation.)

The key results are given in the tables below. Table 13.1 shows the variations in output volatility between the three periods. The standard deviation of the output growth rate in the final decade is less than a half that in the two previous periods, plainly a major improvement. One surprise is that the boom-bust period does not appear to be more unstable than the stop-go period, with the two periods having roughly the same standard deviations of the output growth rate. However, this is largely due to extreme output fluctuations in the immediate aftermath of the Second World War. Output fell heavily in 1946 because of demobilization, while the severe winter of 1947 also hit production badly. Conditions returned to normal only in 1948 and 1949, and arguably a more valid alternative period for comparison runs from 1949 Q1 to 1971 Q2. The standard deviation of the output growth rate in this slightly shorter period is appreciably lower, at 1.94 .

The effect of excluding the highly disrupted first three post-war years is therefore to make the stop-go period more stable than the boom-bust

\section{Table 13.1 Output volatility in three post-war periods}

The figures below relate to the annual (that is, four-quarter) change in gross domestic product (in market prices, with constant 1995 prices). The series analysed is quarterly.

1. The stop-go period, 1945 Q3-1971 Q2

Mean output growth rate

Standard deviation of output growth rate

2. The boom-bust period, 1971 Q3-1992 Q3

Mean output growth rate

Standard deviation of output growth rate

3. The decade of stability after September 1992

Mean output growth rate

Standard deviation of output growth rate

Sources: National Statistics website, and calculations by author and Mr Richard Wild of Cardiff Business School. 
period, in accordance with the historical stereotypes. But it is worth noting that the difference between the standard deviations of the output growth rate in the final decade of stability (1.94 minus 1.01, or 0.93), and the post1949 stop-go period, is greater than the difference between them in the post-1949 stop-go period and the boom-bust period (2.69 minus 1.94, or 0.75 ). As the stop-go era was commonly regarded by contemporaries as enjoying impressive economic stability compared with the inter-war period, and as it continued to be lionized for this reason during the boom-bust years, the scale of policy-makers' achievement of the 1990s emerges yet more emphatically. ${ }^{3}$

While the output growth comparison demonstrates that the postSeptember 1992 decade was very good compared with both the stop-go and boom-bust periods, the inflation comparison is even more favourable. Indeed, the stability of inflation in the ten years from September 1992 has to be described as astonishing after all the mishaps and wrong turnings in British macroeconomic policy in the preceding 45 years. Inflation targets were introduced by the Chancellor of the Exchequer, Mr Norman (now Lord) Lamont, in October 1992. The annual increase in RPIX was to be kept within a 1-per-cent-to-4-per-cent band for the rest of the Parliament (which lasted to 1997), with a hope that it would be towards the lower end of the band by the Parliament's end. In 1997 the newly elected Labour government reiterated the $2 \frac{1}{2}$ per cent RPIX target as well as announcing the radical institutional change of making the Bank of England independent. The Bank's Monetary Policy Committee was given the job of keeping the annual RPIX increase 1 per cent either side of the $2^{1} \frac{1}{2}$ per cent figure. In short, the UK had an inflation target - to be understood as a $2 \frac{1}{2}$ per cent annual increase in RPIX - more or less without interruption for a decade.

What happened? The answer - given in Table 13.2 - is that the mean increase in RPIX in the 38 quarters to 2002 Q2 was 2.6 per cent, with a standard deviation of 0.41 . So the target was met almost exactly. By contrast, in the boom-bust period the comparable measure of retail price inflation averaged 9.6 per cent with a standard deviation of 5.66. Not only did the UK cut inflation in the post-ERM decade to almost a quarter of the figure seen in the previous 20 years, but it also reduced the volatility of inflation to less than a tenth of the former level! Inflation was not much lower in the final decade than in the 1950s and 1960s, but it was significantly more stable. Overall, the verdict has to be highly complimentary to policymakers' record in reducing and stabilizing inflation.

The last variable to be considered is the rate of interest. Here, too, the postERM decade stands out as by far the most stable phase in the 57 years of post-war experience, with markedly better macroeconomic management than the preceding boom-bust period. Table 13.3 shows that the mean 
Table 13.2 Measures of inflation in three post-war periods

I. Inflation measured by the all-items retail price index

The figures below relate to the annual change in the all-items retail price index. The series analysed is a quarterly average of the monthly values.

The stop-go period, 1945 Q3-1971 Q2

Mean annual inflation rate

Standard deviation of inflation rate

The boom-bust period, 1971 Q3-1992 Q3

Mean annual inflation rate

Standard deviation of inflation rate

The decade of stability after September 1992

Mean annual inflation rate

Standard deviation of inflation rate

\section{Inflation measured by RPIX, that is, retail price index excluding mortgage interest payments}

The figures below relate to the all-items retail price index until the first quarter 1976, but to RPIX thereafter. As above, the series analysed is a quarterly average of the monthly values.

The boom-bust period, 1971 Q3-1992 Q3

Mean annual inflation rate

Standard deviation of inflation rate

The decade of stability after September 1992

Mean annual inflation rate

Treasury bill rate in the 1992 Q4-2002 Q2 period was 5.83 per cent, with a standard deviation of 0.70 . In the boom-bust period the mean Treasury bill rate was 10.55 per cent, with a standard deviation of 2.65 , and in the stop-go period it was 3.72 per cent, with a standard deviation of 2.36 . So - when measured in this way - the volatility of interest rates in the post-ERM decade was less than a third that in either the boom-bust or the stop-go period.

The contrast between the UK's macroeconomic performance before and after September 1992 - between the post-ERM decade and the two previous periods of stop-go and boom-bust - is therefore obvious, easily quantified and clear. The post-1992 period was far more stable than the boom-bust period, and it also had a far better record than the generally acclaimed stop-go period. It is time to move on to the more interesting and difficult question of explanation. Why was the UK economy so much more stable after September 1992 than before? 
Table 13.3 Measures of interest rate volatility in three post-war periods

The figures below relate to the quarterly average of the Treasury bill rate.

1. The stop-go period, 1945 Q3-1971 Q2

Mean interest rate

$3.72 \%$

Standard deviation of interest rate

2. The boom-bust period, 1971 Q3-1992 Q3

Mean interest rate

Standard deviation of interest rate

3. The decade of stability after September 1992

Mean interest rate

$5.83 \%$

Standard deviation of interest rate

0.70

Sources: National Statistics website, and calculations by author and Mr Richard Wild.

Budd's answer in his lecture was institutional. In his view, the explanation for the greater stability was to be sought in the design of the system, with 'the establishment of a clearly-defined task', 'the structure of the Committee' and 'the requirement for transparency in the decision-taking process'. The clarity of the task's definition stemmed from the technical nature of the objective. It was to meet the inflation target, with no awkward political distractions on unemployment, growth or the exchange rate. (Of course, unemployment, growth and the exchange rate all mattered, but there were no explicit objectives for any of them.) Transparency was important, because there would be 'no hiding place'. In contrast to the Treasurydominated and largely secret system of decision-taking before 1992, policy-makers' views and voting records would move into the public domain. If they were wrong, it would be their fault and not that of anyone else. In short, the big changes in the system of decision-taking after 1992 were that policy became focused on one and only one objective, and that the people involved were made fully accountable for mistakes.

Budd did not see the change in government in 1997 as a major break. The Treasury Panel of 'wise men', which started business in early 1993, was not a decision-taking body. But all its deliberations were on the record and it therefore played a role in introducing transparency to policy advice. In 1993 the Chancellor of the Exchequer, Mr Kenneth Clarke, announced that the minutes of the regular meetings between him and the Governor would be published, and Budd's lecture saw these meetings as foreshadowing the more complete transfer of power to the Bank in 1997. The Bank of England's Inflation Reports also pre-dated operational independence in 1997, and are evidently considered by Budd to have had an influence on 
decision-taking between 1993 and 1997. (The Inflation Reports informed the Governor's position in his meetings with the Chancellor.) So, when the Monetary Policy Committee was founded, it continued 'an established system'. ${ }^{4}$

\section{II}

Institutions are vital, but an emphasis on a change in institutional structures is surely an incomplete way to explain the radical improvement in policy-making that seems to have occurred. It is also necessary to discuss policy-makers' beliefs and attitudes. The first 45 years of the post-war period were marked by constant intellectual warfare between different tribes of British economists. Indeed, disagreement is popularly seen as a hallmark of modern economics and generates several standard jokes about the profession. But one theme of Budd's lecture was that the excellence of the decisions taken after 1992 reflected the domination of the decisiontaking process by economists. This would make sense only if economists shared a consensus view on the determination of inflation, a view that was well known and relatively uncontroversial to them but not familiar to people from other walks of life. (Budd did not say so in as many words, but his lecture implied that politicians, bankers, civil servants, trade unionists and so on should be kept out of monetary policy.)

The question becomes, "what was the consensus about the determination of inflation that was so extensively shared by the Treasury Panel before 1997, the Monetary Policy Committee after 1997, and by the large numbers of other economist advisers and commentators both within and outside the official machine in these years?' It is important to be clear that the policy achievements of the 1990s were not due to the adoption of the most wellpublicized prescriptions of the most well-known schools of thought. In particular, the simpler versions of neither 'Keynesianism' nor 'monetarism' were relevant.

A discussion of these two tribal belief-systems is needed, if only to knock down some of the totem poles in macroeconomic debate. An influential view in Britain until the 1980s is that Keynesianism - in some shape or form - was responsible for the stability and prosperity of the immediate post-war decades. According to Shirley (now Lady) Williams writing in 1981, after the Second World War 'government planning, public finance and government intervention were used to bring about and sustain full employment and economic growth; deficit spending maintained demand during periods of recession ... The lessons of Maynard Keynes, set out in The General Theory of Employment, Interest and Money, had been 
devotedly learned'. ${ }^{5}$ Wynne Godley, a member of the Treasury Panel in the early 1990s, had written in 1983 that the 25 years after 1945 seemed at the time 'a period of remarkable success with regard to all the main objectives of macroeconomic policy' and that this post-war prosperity was 'the consequence of the adoption by governments of "Keynesian" policies'. ${ }^{6}$

This view of the beneficence of the so-called 'Keynesian revolution' is heard less often nowadays, but it continues to lurk behind many debates about the state and the economy. It needs to be remembered that Keynesianism, in the version adopted by the British centre left in the postwar period, is a political doctrine about the optimal size of the state sector as well as a set of economic prescriptions about how to maintain full employment. In the final chapter of The General Theory, Keynes claimed that 'a somewhat comprehensive socialisation of investment will prove the only means of securing an approximation to full employment'. ${ }^{7}$ This argument was part of the case for nationalization in the late 1940s, and remained central to the defence of the mixed economy until the 1980s. As Crosland recognized in The Future of Socialism (first published in 1956): "Many liberal-minded people, who were instinctively "socialist" in the 1930s ... have now concluded that "Keynes-plus-modified-capitalismplus-Welfare-State" works perfectly well.'8

The current research exercise throws a different and much more sceptical light on the macroeconomic outcomes of the 1950s and 1960s. Crucially, the UK economy was far more stable in the 1990s than in the apogee of the Keynesian revolution. It has been shown that in the post-ERM decade the standard deviation of output growth was lower than in the years from 1945 to 1971, and it remained more stable when the troublesome 1945-47 period was excluded from the comparison. Further, inflation and interest rates were far less volatile in the 1990s than in the immediate post-war decades. Ironically, the inflation rate was the only variable which was not markedly worse during the period of the supposed Keynesian revolution. (Over the 26 years to 1971 it was just under 4 per cent. Many self-styled Keynesians profess themselves indifferent to inflation. ${ }^{9}$ )

But it is implausible to claim that the UK's policies were still Keynesian in the 1990s. They certainly were not Keynesian in the Williams' sense of government planning and intervention. On the contrary, the Conservative government from 1979 to 1997 was more committed to the free market than any of its post-war predecessors. In fact, public ownership was in retreat in the early 1990s, with the main energy utilities being privatized and their markets liberalized. But policies were not even Keynesian in the more humdrum sense that government spending and taxation were being varied to influence employment. Instead, fiscal policy was subordinate to the principle that the budget should be balanced over the course of the business 
cycle. The long-term aim of the budget-balance rule was to prevent excessive growth of the public debt. Not one of the many policy statements from the Treasury in the 1990s envisaged an employment-promoting role for fiscal policy. ${ }^{10}$

So it was not Keynesianism that delivered the macroeconomic stability of the post-ERM decade. What about monetarism? Lamont's announcement of the inflation target in October 1992 was remarkably wide-ranging in its references to variables that policy-makers would have to follow in future. It did mention monitoring ranges for money supply growth, including the concept of 'broad money' which Nigel Lawson had stopped targeting in 1985. But this was a charade. The Treasury itself pretended to be interested in narrow money (particularly as measured by the narrowest possible money measure, M0), but had ignored an overshoot on M0 in the late 1980s, and its officials were not worried about broad money. Most members of the Treasury Panel did not want a discussion of monetary developments to figure in their meetings. It was only after a strong protest by one member of the Panel that a section on money was put on the agenda. ${ }^{11}$ From the outset, the Bank of England's Inflation Report did include extensive material on the monetary aggregates, but at least one of the Bank's published statements on the transmission mechanism of monetary policy pays scant attention to the quantity of money on any definition. ${ }^{12}$ Indeed, when the Bank was given operational independence in 1997, it ended the monitoring range for broad money which had been in place from 1992. According to an article in the Bank's Quarterly Bulletin, the justification was that '[o]ver policy-relevant time horizons, the monetary aggregates will be influenced by many factors, such as cyclical shifts in the demand for money and credit, and innovations in financial structure, products and regulation'. ${ }^{13}$

So monetarism - in the sense of money-target monetarism - had almost no relevance to policy-making in the decade after 1992. Like Keynesianism, it cannot take any credit for the improved performance. However, monetarism encompasses a wide range of attitudes and beliefs. While most British economists have never been enthusiasts for money supply targets, a clear professional consensus emerged in the 1980s and 1990s that one element in monetarist thinking was right. This was the view that there is no long-run trade-off between, on the one hand, output and employment and, on the other, inflation. Indeed, the emergence of this consensus was critical to the adoption of a policy-making framework focused on an inflation target. The rationale for the focus on inflation, and so for the demotion of full employment as a policy objective, had first been presented in the late 1960s. The seminal analysis was given by Milton Friedman, the leader of monetarist thought, in his presidential address to the American Economic Association in $1967 .{ }^{14}$ 
The heart of Friedman's argument was that economic agents were rational. In particular, they could not be deceived by inflationary policymaking. Crucially, pay bargains would be affected by inflationary expectations. If unemployment fell beneath a particular rate (which he called 'the natural rate'), workers and employers would agree a pay rise large enough not only to eliminate the excess demand for labour, but also to compensate for expected inflation. The pay rise would therefore add to next year's inflation and so aggravate inflation expectations further. Next year's pay rise would have to be higher yet again. The logical conclusion was that while unemployment stayed beneath the natural rate - pay bargains and inflation would rise indefinitely. The only rate of unemployment consistent with stable inflation was the natural rate at which the demand for labour was in balance with the supply.

Government attempts to drive unemployment beneath the natural rate would lead not to high and stable inflation, but to hyper-inflation. Friedman was evasive about certain aspects of his argument. For example, he denied that central banks could measure the natural rate, even though one of his most famous early papers had emphasized the need to develop theories that were testable against data. ${ }^{15}$ Other economists were not so cautious. It is, in fact, a simple matter to prepare series for unemployment, the rate of wage increases and the change in the rate of wage increases, and to carry out some econometric tests. Despite many problems of interpretation, economists have been able to derive estimates of the natural rate and to see whether Friedman's 'accelerationist hypothesis' is valid. In country after country the answer has been that - on the whole - it does fit the facts or, when there is some lack of clarity in the data, that Friedman's hypothesis is more convincing than the alternatives.

But labour market institutions - like financial regulation - are evolving all the time. To base monetary policy on an unemployment rate would be not only politically contentious, but also technically difficult. The key to applying Friedman's doctrine to policy-making was a generalization of the natural-rate idea. Instead of emphasizing that there is an unemployment rate at which inflation is stable, economists suggested that there is a level of output ('trend' or 'sustainable output', or even 'the natural rate of output') at which inflation is stable. (At this level of output the demand for labour should be broadly in balance with the supply, with unemployment at the natural rate. But other markets and factors of production are relevant. Ideally, output is at trend when machine capacity is working at a normal utilization level, the office vacancy rate is at a level associated with a stable rate of rent increases, the proportion of the nation's fleet of freight lorries is such as freight charges are increasing at a stable rate, and so on.) When output is above the trend level, there is said to be a positive 'output gap'; 
when it is beneath the trend level, the output gap is negative. Friedman's insight (that is, the absence of a long-run unemployment/inflation tradeoff) is captured, more or less, by the proposition that the change in inflation is a positive function of the level of the gap.

The implied approach to monetary policy was simple. In late 1992 the UK undoubtedly had a large negative output gap after the recession induced by the ERM. It could therefore enjoy several quarters, perhaps even a few years, of above-trend growth without any serious risk of rising inflation. ${ }^{16}$ After a year of very strong growth in 1994 output had returned roughly to its trend level (that is, the output gap was roughly zero) and the annual rate of RPIX inflation was about $2 \frac{1}{2}$ per cent. Since then, monetary policy - to be understood almost wholly as changes in short-term interest rates - has been organized to keep the output gap at close to zero. According to the theory, by keeping the output gap at roughly nil, inflation should be stable. In the event, policy has been successful in keeping the output gap at close to zero, and inflation has stayed remarkably steady at about $2 \frac{1}{2}$ per cent. Here - in essence - is the explanation for the almost 15 years of stability from $1992 .{ }^{17}$

In his 'Quest for stability' lecture, Budd acknowledged that this theory had motivated the official approach to monetary policy after the UK's exit from the ERM. He noted that British governments had a long record of trying to maximize output and increase employment, and yet the result had been over-full employment, excessive inflation and macroeconomic instability. But the new theory implied that the key to maintaining stability of inflation was to have 'output stability'; and, in his words, 'that is, in effect, what the MPC does. It seeks to keep output as close as it reasonably can to its sustainable level, since that is usually a necessary condition for inflation stability'. Budd did not elaborate the point, but - if the sentences here are to be dignified with a theoretical label - output-gap monetarism seems the most fitting.

\section{III}

Output-gap monetarism is hardly complicated. Although its adoption has been particularly successful in the UK, it now provides the dominant theoretical basis for central banking around the world. It has not eliminated the need for judgement and discretion in policy-making, as there are many difficulties in estimating the output gap and projecting its future course. Nevertheless, it helps to explain why the 1990s were a stable decade not just in the UK but in many other economies too (including, crucially, the USA). The puzzle is, surely, why it took economists in governments, central banks, 
financial institutions and universities so long to find, develop and accept the key ideas. In the UK the trouble may have stemmed partly from the prestige attached to Keynesian economics, with its very different concepts and emphases, and partly from many politicians' obstinate enthusiasm for basing monetary policy on the exchange rate. ${ }^{18}$ (The appendix to the Introduction of this collection argued that the idea of the output gap evolved among practitioners - at the IMF and the OECD, and in broker research departments - in the late 1980s, simply because there was a demand for answers to certain kinds of question.)

But the role of the natural rate of unemployment and the output gap in monetarist economics is also a little uncomfortable. There is no doubt that output-gap monetarism is derived from the accelerationist hypothesis, but Friedman himself failed to see the potential of his 1967 lecture for policymaking. Instead of advertising the positive agenda for stabilization implied by his ideas, he made a needlessly cautious remark about the difficulty of measuring the natural rate, and delivered a vital but entirely negative comment on full employment policies. Further, the apparent triumph of output-gap monetarism does not mean the debates are over. There are still too many muddles about the role of the money in the determination of demand and output, and continued disagreement about the tasks of the central bank and the status of different monetary aggregates in policy-making.

\section{NOTES}

1. A. Budd, 'The quest for stability', Julian Hodge Institute of Applied Macroeconomics annual lecture, Cardiff, annual lecture given on 25 April 2002. (Printed as a pamphlet jointly by Cardiff Business School and Julian Hodge Bank.) The lecture was republished in the autumn 2002 issue of World Economics, vol. 3, no. 3.

2. The author received help from Mr Richard Wild, then of Cardiff Business School and now at the Office for National Statistics, in the preparation of the data.

3. See pp. 269-70 and notes 5, 6 and 8 below for the belief that the first 25 years were unusually stable because of Keynesian policies.

4. Budd's emphasis on the continuity of policy from 1992 contrasts with claims of a sharp discontinuity in 1997 in Reforming Britain's Economic and Financial Policy, a collection of Treasury papers and speeches edited by Ed Balls and Gus O'Donnell. In the foreword to this book, Mr Gordon Brown, the Chancellor of the Exchequer, said, 'My first words from the Treasury . . . were to reaffirm for this government our commitment to the goal set out in 1944 of high and stable levels of growth and employment, and to state that from 1997 onwards the attainment of this goal would require a wholly new monetary and fiscal framework.' A few sentences later Brown talked of 'a new paradigm' in 1997. (E. Balls and G. O'Donnell [eds], Reforming Britain's Economic and Financial Policy [Basingstoke and New York: Palgrave, 2002], p. x.)

5. S. Williams, Politics is for People (Harmondsworth: Penguin, 1981), p. 17.

6. W. Godley and F. Cripps, Macroeconomics (Oxford: Oxford University Press, also in Fontana paperback, 1983), pp. 13-14. 
7. J.M. Keynes, The General Theory (London: Macmillan, paperback edition 1964, originally published 1936), p. 378.

8. C.A.R. Crosland, The Future of Socialism (New York: Schocken paperback edition, 1963), p. 79.

9. See, for example, Hahn's comment in the 1981 Mitsui lectures that 'inflation as such is not an outstanding evil, nor do I believe it to be costly in the sense that economists use that term'. (F. Hahn, Money and Inflation [Oxford: Blackwell, 1982], p. 106)

10. The September 2002 issue of Euromoney magazine included a quotation (p. 67) from Joseph Stiglitz, the Nobel-prize-winning economist, to the effect that 'Gordon Brown is a new Keynesian'. The September 2002 issue of Institutional Investor magazine carried an interview with Brown where he said, 'We've reduced [public] debt very substantially in Britain, from 44 per cent of national income to 30 per cent . . . So we are fiscal disciplinarians'. If Keynesianism is to be equated with fiscal discipline, then Picasso's Guernica was stimulated by T.S. Eliot's poetry and Maoism was heavily indebted to John Stuart Mill. Perhaps - by the phrase 'New Keynesianism' - Stiglitz meant the adjustment of interest rates according to the level of the output gap. But - as explained in the appendix to the Introduction - the label 'New Keynesian' is misapplied to this policy prescription.

11. At its first meeting in early 1993, five out of the seven members of the Treasury Panel did not want its reports to include a section on monetary developments. The author of this essay wrote two Open Letters to the other members of the Panel, urging that a section on money was needed. (See the March and April 1993 issues of the Gerrard \& National Monthly Economic Review.) Thereafter, a section on monetary developments did become part of the Treasury Panel's agenda.

12. See the note on 'The transmission mechanism of monetary policy' delivered to the Treasury Committee of the House of Commons and the House of Lord Select Committee in May 1999. The note is also discussed in note 9 to Essay 14.

13. A. Hauser and A. Brigden, 'Money and credit in an inflation-targeting regime', autumn 2002, pp. 299-307, Bank of England Quarterly Bulletin. The quotation is from p. 299.

14. The address was republished in Milton Friedman, The Optimum Quantity of Money (London: Macmillan, 1969), pp. 95-110.

15. In a 1952 essay 'The methodology of positive economics', Friedman argued that economic theory generated 'a body of generalizations' whose validity stemmed from 'the accuracy of their predictions'. ('The methodology of positive economics', Essays in Positive Economics [Chicago and London: University of Chicago Press, 1953], pp. 3-43.)

16. '[A]bove-trend growth can be reconciled for several years with low inflation.' (Submission by Professor Tim Congdon of Lombard Street Research in the February 1993 report of the Panel of Independent Forecasters [London: HM Treasury, 1993], p. 25.)

17. See also pp. 9-11 of the June 1999 issue of Lombard Street Research's Monthly Economic Review, with Lord Burns' lecture on Lombard Street Research's tenth birthday. (The lecture was called 'The new consensus on macroeconomic policy: will it prove temporary or permanent?'.)

18. N. Lawson, The View from No. 11 (London and New York: Bantam Press, 1992), passim. (See also Essay 3 in this collection for British economists' fondness for basing interest rates on the exchange rate.) 


\section{APPENDIX: DID STABILITY EXTEND BEYOND Q3 2002?}

The paper on which Essay 13 is based was written in September and October of 2002, and published in the October-December 2002 issue of World Economics. At the time of writing (mid-2006) a further 14 quarters of data (that is, Q4 2002-Q2 2006) have become available. Do they change the message of the essay?

The short answer is 'no, on the contrary, they enhance it'. Table 13.4 sets out the key numbers. The average growth rate of output in the period after Q4 2002 was a shade lower than in the post-ERM decade, but also with slightly less volatility. The inflation record would be complicated if numbers were given for the consumer price index (CPI), which in 2003 became the measure in which the official target was expressed. However, it is sufficient to keep to the two retail price indices, given the shortness of the experience with the CPI. At any rate, if the RPIX target had been kept at 2.5 per cent, it would have been met on average in the 14 quarters to Q2 2006 and the variability of this inflation rate was even lower than in the post-ERM decade! Finally, interest rates were lower and more stable in the period under review here than in any comparable period in the UK's post-war experience.

Of course, none of the above should be read as a guarantee of continuing stability, but - at the time of writing - the record remains impressive.

Table 13.4 Measures of volatility in key economic series, in 14 quarters from end of 2002

\begin{tabular}{lcc}
\hline & Q4 1992-Q2 2006 & Q4 2002-Q2 2006 \\
\hline GDP at constant 2003 prices & 2.9 & 2.6 \\
Average growth rate, \% & 0.81 & 0.61 \\
Standard deviation of growth rate & & \\
All-items Retail Price Index & 2.56 & 2.85 \\
Average annual increase, \% & 0.74 & 0.30 \\
Standard deviation of annual increase & & \\
RPIX & 2.53 & 2.45 \\
Average annual increase, \% & 0.38 & 0.29 \\
Standard deviation of annual increase & & \\
Treasury bill yield & 5.29 & 4.28 \\
Average value & 1.04 & 0.47 \\
Standard deviation & &
\end{tabular}

Source: Office for National website and author's calculations. 